\title{
Effect of legume-cereal mixtures for weed infestation
}

\section{Wpływ mieszanek strączkowo-zbożowych na zachwaszczenie łanu}

\author{
Wiesław Wojciechowski ${ }^{1}$, Marcin Kozak², Monika Białkowska ${ }^{2}$, Marta Ćwiertniewska ${ }^{2}$
}

\section{Summary}

Legumes are regarded as cultivated plants fulfilling the requirement of sustainable agriculture. Cultivations of legumes in pure sowing is quite risky and often unprofitable. Therefore, the mixtures of these plants with cereal crops are of special value. Simultaneous cultivation of two plant from different families may cause some problems related to the protection of crops against weeds. Properly selected composition of the mixture components may result in high productivity effects and significantly influence the development of weed infestation. The aim of the study was to determine the effect of faba bean grown simultaneously with spring triticale on weed infestation different density of plants per unit area unit was tested. It was shown that with increasing share of the cereal crops in the mixture with field bean the number and dry weight of weeds were considerably reduced species. Dominant weeds in weed infestation were Chenopodium album L., Galinsoga parviflora Cav., Thlaspi arvense L., Capsella bursa-pastoris L., Galium aparine L. and Viola arvensis Murr.

Key words: legume-cereale mixtures, faba bean, spring triticale, weed infestation

\section{Streszczenie}

Do roślin spełniających warunki rolnictwa zrównoważonego należą gatunki strączkowe, których uprawa w siewie czystym, w warunkach Polski, jest dość zawodna i często nieopłacalna, dlatego ważne znaczenie odgrywają mieszanki tych roślin ze zbożami. Jednoczesna uprawa dwóch gatunków roślin należących do różnych rodzin niesie za sobą pewne problemy związane z ochroną łanu przed chwastami. Odpowiednio dobrany skład komponentów mieszanki, obok efektów produkcyjnych, może wpłynąć istotnie na kształtowanie zachwaszczenia łanu tych roślin. Celem badań było określenie wpływu uprawy współrzędnej bobiku z pszenżytem jarym, przy różnym zagęszczeniu roślin na jednostce powierzchni, na zachwaszczenie łanu. Wykazano, że w miarę zwiększania udziału rośliny zbożowej w mieszance z bobikiem, ograniczeniu ulegała liczebność i sucha masa chwastów. Chwastami dominującymi w zachwaszczeniu łanu były: Chenopodium album L., Galinsoga parviflora Cav., Thlaspi arvense L., Capsella bursa-pastoris L., Galium aparine L. oraz Viola arvensis Murr.

Słowa kluczowe: mieszanki strączkowo-zbożowe, bobik, pszenżyto jare, zachwaszczenie

\footnotetext{
Uniwersytet Przyrodniczy we Wrocławiu Pl. Grunwaldzki 24A, 50-363 Wrocław

${ }^{1}$ Katedra Kształtowania Agroekosystemów i Terenów Zieleni wieslaw.wojciechowski@up.wroc.pl

${ }^{2}$ Katedra Szczegółowej Uprawy Roślin
} 


\section{Wstęp / Introduction}

Przekroczenie dopuszczalnego progu 60-65\% udziału zbóż w strukturze zasiewów wpływa często na nasilenie występowania chorób i szkodników roślin (Kurowski i wsp. 1992; Blecharczyk 2002) oraz zwiększenie inwazyjności chwastów (Wojciechowski i Zawieja 2007), co następnie znajduje odzwierciedlenie w konieczności stosowania większej ilości środków ochrony roślin. Wielu autorów (Idziak i Michalski 2003; Buczek i wsp. 2007; Sobkowicz i Podgórska-Lesiak 2007) wskazuje na możliwość wykorzystania do zwalczania chwastów naturalnej i proekologicznej metody regulacji zachwaszczenia, jaką jest uprawa współrzędna roślin. Z doniesień literaturowych (Wanic i wsp. 2004; Buczek i wsp. 2007) wynika, że uprawa mieszanki może zarówno ograniczać koszty odchwaszczenia i tym samym nie zanieczyszczać środowiska oraz produktów roślinnych różnymi substancjami czynnymi środków ochrony roślin. Jest to szczególnie ważny aspekt w szeroko rozumianym rolnictwie ekologicznym i integrowanym.

Rośliny strączkowe, pomimo że spełniają założenia i warunki rolnictwa zrównoważonego obecne są w Polsce na niewielkim areale, ponieważ ich uprawa w siewie czystym jest często zawodna i nieopłacalna. Dlatego, aby wykorzystać potencjał hodowlany gatunków/odmian strączkowych należy poszukiwać rozwiązań, które umożliwiłyby zarówno stabilizację poziomu plonowania tych roślin w zmiennych warunkach gospodarowania, jak i ograniczyły nakłady na samą produkcję. Jednym z takich rozwiązań jest uprawa międzygatunkowa roślin strączkowych ze zbożami. Wprawdzie niesie ona ze sobą określone problemy związane $\mathrm{z}$ ochroną łanu przed zachwaszczeniem, lecz mimo tego uważa się, że prawidłowy dobór komponentów mieszanki umożliwia jego ograniczenie. Ze względu na duże zróżnicowanie morfologiczne komponentów mieszanek strączkowo-zbożowych przypisuje się im zdolności odchwaszczające (Haymes i Lee 1999). Według Creamera i wsp. (1996), taki stan wynika z dokładniejszego pokrycia gleby przez poszczególne komponenty mieszanek, a co jest $\mathrm{z}$ tym związane utrudnia wzrost kiełkującym chwastom.
Celem badań było określenie wpływu uprawy współrzędnej bobiku z pszenżytem jarym, przy różnym zagęszczeniu roślin na jednostce powierzchni, na zachwaszczenie łanu.

\section{Materiały i metody / Materials and methods}

Podstawą przeprowadzonych badań było dwuczynnikowe doświadczenie polowe założone w latach 2010-2012 na polach doświadczalnych Katedry Szczegółowej Uprawy Roślin Uniwersytetu Przyrodniczego we Wrocławiu w Pawłowicach. Doświadczenie założono, w trzech powtórzeniach, w układzie „split-plot”, na glebie należącej do działu gleb autogenicznych, rzędu brunatno-ziemnych, typu płowego, podtypu typowe, wytworzonej z gliny lekkiej na glinie średniej, zaliczanej do kompleksu przydatności rolniczej pszennego dobrego, klasy bonitacyjnej IIIb.

Czynnikiem badawczym pierwszego rzędu były odmiany bobiku (Albus, Mistral), natomiast czynnikiem drugiego rzędy był zróżnicowany udział komponentów mieszanek wyrażony liczbą wysianych nasion/ziaren na $1 \mathrm{~m}^{2}$ (tab. 1).

Wiosna przed siewem zastosowano na 1 ha $60 \mathrm{~kg} \mathrm{P}_{2} \mathrm{O}_{5}$ w formie superfosfatu potrójnego $46 \%, 100 \mathrm{~kg} \mathrm{~K} 2 \mathrm{O}$ w formie soli potasowej $60 \%$ oraz $30 \mathrm{~kg} \mathrm{~N}$ w postaci saletry amonowej 34\%. Dodatkowo w fazie strzelania w źdźbło na poletkach $\mathrm{z}$ siewem czystym pszenżyta zastosowano uzupełniająca dawkę azotu (30 kg/ha) w postaci saletry amonowej 34\%. Ze względu na charakter doświadczenia nie stosowano chemicznych zabiegów herbicydowych.

W fazie końca kwitnienia bobiku i kłoszenia pszenżyta określono, na każdym poletku (poletko $15 \mathrm{~m}^{2}$ ), skład gatunkowy oraz liczbę i suchą masę chwastów w trzech losowo wybranych miejscach, wyznaczonych ramką o wymiarach $0,5 \mathrm{~m} \times 0,5 \mathrm{~m}$. Wartość produkcyjną mieszanek wyrażono jednostkami zbożowymi w odniesieniu do plonów głównych uprawianych roślin (Harasim 2006).

Uzyskane dane poddano analizie wariancji, a istotność różnic między średnimi weryfikowano testem t-Studenta na poziomie ufności $\alpha=0,05$.

Tabela 1. Liczba wysianych nasion/ziaren na $1 \mathrm{~m}^{2}$

Table 1. Number of sown seeds/grains per $1 \mathrm{~m}^{2}$

\begin{tabular}{c|c|c}
\hline \multicolumn{2}{c|}{ Liczba wysianych nasion/ziaren na $1 \mathrm{~m}^{2}-$ Number of sown seeds/grains per 1 $\mathrm{m}^{2}$} & \multirow{2}{*}{$\begin{array}{c}\text { Ilość wysianego bobiku [\%] } \\
\text { Quantity sown of faba bean [\%] }\end{array}$} \\
\hline $\begin{array}{c}\text { Bobik (Albus lub Mistral) } \\
\text { Faba bean (Albus or Mistral) }\end{array}$ & $\begin{array}{c}\text { pszenżyto jare (Milkaro) } \\
\text { spring triticale (Milkaro) }\end{array}$ & 100 \\
\hline 60 & - & 80 \\
\hline 48 & 80 & 60 \\
\hline 36 & 160 & 40 \\
\hline 24 & 240 & 20 \\
\hline 12 & 320 & 0 \\
\hline
\end{tabular}




\section{Wyniki i dyskusja / Results and discussion}

W warunkach przeprowadzonego doświadczenia stwierdzono istotny wpływ zróżnicowanej ilości wysiewu poszczególnych komponentów mieszanek na liczbę (tab. 2) oraz na suchą masę chwastów (tab. 3). Największe zachwaszczenie obserwowano w siewie czystym bobiku (60 nasion $/ \mathrm{m}^{2}$ ) (tab. 2) i było ono niezależne od wysiewanej odmiany ponad dwuipółkrotnie większe niż w siewie czystym pszenżyta. Zmniejszenie o $20 \%$ udziału rośliny strączkowej $\mathrm{w}$ mieszance spowodowało redukcję zachwaszczenia o około $36 \%$ w mieszance pszenżyta z bobikiem odmiany Mistral i o $21 \%$ w mieszance pszenżyta $\mathrm{z}$ bobikiem odmiany Albus. Dla suchej masy chwastów różnice te były jeszcze bardziej widoczne i kształtowały się sześciokrotnie wyżej niż w siewie czystym pszenżyta. Badania własne potwierdzają wcześniejsze wyniki opisane przez Buraczyńską (2009), która wykazała, że w łanie łubinu wąskolistnego z owsem liczba chwastów w siewie czystym była czteroipółkrotnie większa niż w zasiewach mieszanych. Autorka ta odnotowała również znaczące różnice $\mathrm{w}$ odniesieniu do suchej masy chwastów (ponad ośmiokrotne).

Tabela 2. Liczba chwastów w łanie mieszanki strączkowo-zbożowej [szt. $/ \mathrm{m}^{2}$ ] (średnie $\mathrm{z}$ lat 2010-2012)

Table 2. Number of weeds in legume-cereal mixture [pcs $\left./ \mathrm{m}^{2}\right]$ (means for 2010-2012)

\begin{tabular}{|c|c|c|c|}
\hline \multirow{2}{*}{$\begin{array}{l}\text { Liczba wysianych nasion/ziaren na } 1 \mathrm{~m}^{2} \\
\text { Number of sown seeds/grains per } 1 \mathrm{~m}^{2}\end{array}$} & \multicolumn{3}{|c|}{ Odmiana bobiku - Faba bean cultivar } \\
\hline & Albus & Mistral & średnio - mean \\
\hline $\begin{array}{l}60 \text { nasion bobiku } \\
60 \text { faba bean seeds }\end{array}$ & 26,89 & 20,44 & 23,7 \\
\hline $\begin{array}{l}48 \text { nasion bobiku }+80 \text { ziaren pszenżyta } \\
48 \text { faba bean seeds }+80 \text { triticale grains }\end{array}$ & 21,33 & 13,11 & 17,2 \\
\hline $\begin{array}{l}36 \text { nasion bobiku }+160 \text { ziaren pszenżyta } \\
36 \text { faba bean seeds }+160 \text { triticale grains }\end{array}$ & 13,78 & 15,11 & 14,4 \\
\hline $\begin{array}{l}24 \text { nasion bobiku }+240 \text { ziaren pszenżyta } \\
24 \text { faba bean seeds }+240 \text { triticale grains }\end{array}$ & 10,22 & 11,33 & 10,8 \\
\hline $\begin{array}{l}12 \text { nasion bobiku }+320 \text { ziaren pszenżyta } \\
12 \text { faba bean seeds }+320 \text { triticale grains }\end{array}$ & 10,67 & 10,67 & 10,7 \\
\hline $\begin{array}{l}400 \text { ziaren pszenżyta } \\
400 \text { triticale grains }\end{array}$ & 9,11 & 9,77 & 9,4 \\
\hline NIR $(0,05)-\operatorname{LSD}(0.05)$ & 5,37 & 5,01 & 3,6 \\
\hline Średnio - Mean & 15,3 & 13,4 & - \\
\hline NIR $(0,05)-\operatorname{LSD}(0.05)$ & \multicolumn{2}{|c|}{1,52} & - \\
\hline
\end{tabular}

Tabela 3. Sucha masa chwastów $\left[\mathrm{g} / \mathrm{m}^{2}\right]$ (średnie $\mathrm{z}$ lat 2010-2012)

Table 3. Weight of weed $\left[\mathrm{g} / \mathrm{m}^{2}\right]$ (means for years 2010-2012)

\begin{tabular}{|c|c|c|c|}
\hline \multirow{2}{*}{$\begin{array}{l}\text { Liczba wysianych nasion/ziaren na } 1 \mathrm{~m}^{2} \\
\text { Number of sown seeds/grains per } 1 \mathrm{~m}^{2}\end{array}$} & \multicolumn{3}{|c|}{ Odmiana bobiku - Faba bean cultivar } \\
\hline & Albus & Mistral & $\begin{array}{c}\text { średnio } \\
\text { mean }\end{array}$ \\
\hline $\begin{array}{l}60 \text { nasion bobiku } \\
60 \text { faba bean seeds }\end{array}$ & 16,12 & 23,58 & 19,8 \\
\hline $\begin{array}{l}48 \text { nasion bobiku }+80 \text { ziaren pszenżyta } \\
48 \text { faba bean seeds }+80 \text { triticale grains }\end{array}$ & 6,86 & 8,39 & 7,6 \\
\hline $\begin{array}{l}36 \text { nasion bobiku }+160 \text { ziaren pszenżyta } \\
36 \text { faba bean seeds }+160 \text { triticale grains }\end{array}$ & 6,57 & 5,56 & 6,1 \\
\hline $\begin{array}{l}24 \text { nasion bobiku }+240 \text { ziaren pszenżyta } \\
24 \text { faba bean seeds }+240 \text { triticale grains }\end{array}$ & 5,19 & 5,12 & 5,1 \\
\hline $\begin{array}{l}12 \text { nasion bobiku }+320 \text { ziaren pszenżyta } \\
12 \text { faba bean seeds }+320 \text { triticale grains }\end{array}$ & 2,68 & 2,59 & 2,6 \\
\hline $\begin{array}{l}400 \text { ziaren pszenżyta } \\
400 \text { triticale grains }\end{array}$ & 1,64 & 3,58 & 2,6 \\
\hline NIR $(0,05)-\operatorname{LSD}(0.05)$ & 4,98 & 5,93 & 3,3 \\
\hline Średnio - Mean & 6,5 & 8,1 & - \\
\hline NIR $(0,05)-\operatorname{LSD}(0.05)$ & \multicolumn{2}{|c|}{ r.n. } & - \\
\hline
\end{tabular}

r.n. - różnica nieistotna - not significant difference 


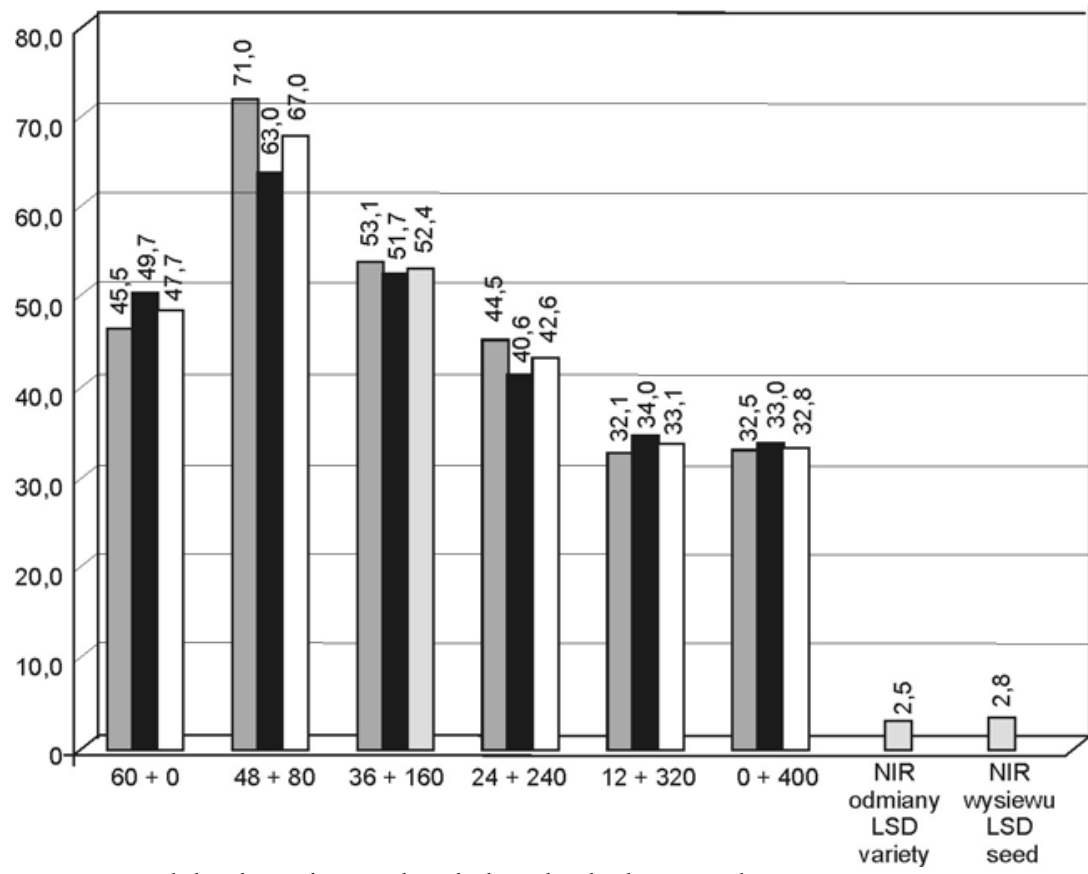

Albus + pszenżyto - triticale

Mistral + pszenżyto - triticale

Średnia - Mean

Rys. 1. Wartość produkcyjna mieszanek w jednostkach zbożowych

Fig. 1. The value of production in units of cereal mixtures

W przeprowadzonym eksperymencie polowym stwierdzono, że wraz ze zmniejszającym się udziałem komponentu strączkowego w mieszance malała zarówno liczba (o 34\% u odmiany Albus i o 48\% u odmiany Mistral), jak i sucha masa chwastów (o 10\% u odmiany Albus i o 15\% u odmiany Mistral) (tab. 2, 3).

Wyniki własne potwierdzają wcześniejsze badania Wendy-Piesik i Rudnickiego (2000), chociaż należy zaznaczyć, że autorzy ci redukcję zachwaszczenia zarówno pod względem liczby, jak i suchej masy ocenili na zdecydowanie niższym poziomie od kilkudziesięciu procent odnośnie liczby do dwukrotności dla suchej masy chwastów. W eksperymencie przeprowadzonym przez Buraczyńską (2009) wykazano, że liczba i powietrznie sucha masa chwastów w łanie mieszanki strączkowo-zbożowej była istotnie mniejsza od liczby i masy chwastów w łanie siewu czystego rośliny strączkowej. Z kolei odmiennie zmniejszenia liczby i masy chwastów nie obserwował w swoich badaniach Kotecki (1990).

Według doniesień literaturowych (Parylak i wsp. 2006; Buczek i wsp. 2007; Sobkowicz i Podgórska-Lesiak 2007) siewy mieszane mogą istotnie ograniczać zachwaszczenie. Idziak i Michalski (2003) oraz Parylak i wsp. (2006) wyjaśniają zmniejszenie zachwaszczenia łanów strączkowo-zbożowych poprzez dużą zdolność konkurencyjną roślin, co jest wynikiem lepszego zwarcia łanu oraz dokładniejszego pokrycia gleby.

W doświadczeniu własnym stwierdzono, że wraz ze zmniejszającym się udziałem komponentu strączkowego (z 60 nasion na $1 \mathrm{~m}^{2}$ do 12 nasion na $1 \mathrm{~m}^{2}$ ), a jednocześnie zwiększającym się udziałem komponentu zbożowego (z 80 ziarniaków na $1 \mathrm{~m}^{2}$ do 400 ziarniaków na $1 \mathrm{~m}^{2}$ ) następował istotny spadek liczby chwastów (tab. 2), jak i suchej masy chwastów (tab. 3).
W przeprowadzonym eksperymencie nie udowodniono istotnego oddziaływania zróżnicowanej ilości wysiewu komponentów mieszanki na skład gatunkowy chwastów. Niewątpliwie chwastami dominującymi w uprawie współrzędnej bobiku z pszenżytem jarym były: Chenopodium album L., Galinsoga parviflora Cav., Thlaspi arvense L., Capsella bursa-pastoris L., Galium aparine L. oraz Viola arvensis Murr.

Produkcyjność mieszanek wyrażona w jednostkach zbożowych zależała głównie od udziału rośliny strączkowej. Najwyższą, niezależnie od odmiany, wykazano w mieszance $\mathrm{z}$ największym udziałem bobiku, a najmniejszym pszenżyta, najniższą natomiast w siewie czystym rośliny zbożowej. Znajduje to potwierdzenie w badaniach Noworolnika (2000) oraz Buraczyńskiej i Ceglarka (2009).

W przeprowadzonym doświadczeniu zmniejszenie udziału bobiku z 48 do 12 nasion na $1 \mathrm{~m}^{2}$ w mieszance z pszenżytem jarym powodowało otrzymanie istotnie mniej jednostek zbożowych mieszanki odpowiednio o 38,9 jednostki dla odmiany Albus i o 29,0 dla odmiany Mistral (rys. 1). Zaobserwowano również wyraźny wpływ stopnia zachwaszczenia na produktywność mieszanki zbożowostrączkowej, co uwidoczniło się szczególnie pomiędzy siewem czystym bobiku, a mieszankami o obsadzie 48 i 36 nasion rośliny strączkowej na $1 \mathrm{~m}^{2}$. Produkcyjność w siewie czystym bobiku mimo, że powinna być najwyższa, najprawdopodobniej w wyniku najsilniejszego zachwaszczenia (najwyższa zarówno liczba, jak i sucha masa chwastów) była o 28,8\% mniejsza niż w mieszance z 48 nasionami bobiku na $\mathrm{m}^{2}$ oraz o $9,0 \%$ mniejsza niż w mieszance z 36 nasionami. Nieco innego zdania są Buraczyńska i Ceglarek (2009), którzy oceniając wydajność mieszanek strączkowo-zbożowych, najlepszą wykazali w siewie czystym bobiku, w którym było jednocześnie największe zachwaszczenie łanu (Buraczyńska 2009). 
Różnica ta jednak może wynikać z tego, że wartościowość mieszanek autorzy wyceniali plonem białka, a nie jednostkami zbożowymi.

\section{Wnioski / Conclusions}

1. Wraz ze zwiększającym się udziałem komponentu strączkowego w mieszankach bobikowo-pszenżytnich zwiększeniu ulegało zachwaszczenie ich łanu.

2. Zmniejszenie udziału bobiku w mieszance zaledwie o $20 \%$ w stosunku do siewu czystego powodowało istotną redukcję zachwaszczenia.
3. Czynnik doświadczenia, jakim była zróżnicowana ilość wysiewu poszczególnych komponentów mieszanek strączkowo-zbożowych nie wpłynął istotnie na skład gatunkowy chwastów występujących w zasiewach mieszanych.

4. Najmniejsze zachwaszczenie łanu odnotowano w siewie czystym pszenżyta jarego.

5. Produkcyjność mieszanek wyrażona w jednostkach zbożowych zależała głównie od udziału rośliny strączkowej.

Zadanie współfinansowane przez Unię Europejską w ramach Europejskiego Funduszu Społecznego.

\section{Literatura / References}

Blecharczyk A. 2002. Reakcja żyta ozimego i jęczmienia jarego na system następstwa roślin i nawożenie w doświadczeniu wieloletnim. Rocz. AR Poznań, Rozp. Nauk. 32, 127 ss.

Buczek J., Tobiasz-Salach R., Bobrecka-Jamro D. 2007. Ocena plonowania i odchwaszczającego działania jarych mieszanek zbożowych. Zesz. Probl. Post. Nauk Rol. 516: 11-18.

Buraczyńska D. 2009. Zachwaszczenie mieszanek strączkowo-zbożowych przy zróżnicowanym składzie ilościowo-jakościowym. Prog. Plant Prot./Post. Ochr. Roślin 49 (2): 779-783.

Buraczyńska D., Ceglarek F. 2009. Plon i skład chemiczny mieszanek strączkowo-zbożowych. Fragm. Agron. 26 (3): 15-24.

Creamer N.G., Bennett M.A., Stinner B.R., Regnier E.E. 1996. Mechanism of weed suppression in cover crop-based production systems. Hort Sci. 31: 410-413.

Harasim A. 2006. Przewodnik Ekonomiczno-Rolniczy w Zarysie. Instytut Uprawy Nawożenia i Gleboznawstwa - Państwowy Instytut Badawczy, Puławy: 74-86.

Haymes R., Lee H.C.1999. Competition between autumn and spring planted grain intercrops of wheat (Triticum aestivum) and field bean (Vicia faba). Field Crops Res. 62: 167-176.

Idziak R., Michalski T. 2003. Zachwaszczenie i plonowanie mieszanek jęczmienia jarego i owsa przy różnym udziale obu komponentów w zasiewie. Zesz. Probl. Post. Nauk Rol. 490: 99-104.

Kotecki A. 1990. Wpływ składu gatunkowego oraz zróżnicowanego udziału komponentów w mieszankach na plon nasion peluszki uprawianych w różnych warunkach glebowych. Zesz. Nauk. AR Wrocław, Rozpr. hab. 87, 54 ss.

Kurowski T., Hruszka M., Sadowski T. 1992. Zdrowotność pszenicy ozimej w specjalistycznych zmianowaniach. Acta Acad. Agricult. Tech. Olst., Agricultura 54: 225-233.

Noworolnik K. 2000. Mieszanki zbożowo-strączkowe w systemie rolnictwa zrównoważonego. Pam. Puł. 120 (2): 325-329.

Parylak D., Zawieja J., Jędruszczak M., Stupnicka-Rodzynkiewicz E., Dąbkowska T., Snarska K. 2006. Wykorzystanie zasiewów mieszanych, właściwości odmian lub zjawiska allelopatii w ograniczeniu zachwaszczenia. Prog. Plant Prot./Post. Ochr. Roślin 47 (3): 271-275.

Sobkowicz P., Podgórska-Lesiak M. 2007. Zmiany w zachwaszczeniu zasiewów czystych i mieszanek dwóch odmian grochu z jecczmieniem pod wpływem nawożenia azotowego. Prog. Plant Prot./Post. Ochr. Roślin 47 (3): 271-275.

Wanic M., Nowicki J., Kurowski P.T. 2004. Zachwaszczenie oraz stan zdrowotności jęczmienia jarego i owsa uprawianych w mieszance i siewach jednogatunkowych. Cz. I. Zachwaszczenie roślin. Prog. Plant Prot./Post. Ochr. Roślin 44 (2): $1191-1193$.

Wenda-Piesik A., Rudnicki F. 2000. Występowanie niektórych agrofagów pszenżyta jarego uprawianego w siewie czystym i w mieszankach. Folia Univ. Agric. Stetin 206, Agricultura: 303-310.

Wojciechowski W., Zawieja J. 2007. Oddziaływanie płodozmianów specjalistycznych na dynamikę zachwaszczenia pól. Pam. Puł. 145: 255-261. 